\title{
Specifics of Rendition of Ukrainian Realia in German-Language Academic Texts (Based On A. Jensen's Monograph Ein Ukrainisches Dichterleben)
}

\author{
Y. Tkachenko
}

\author{
Instutute of Philology, Taras Shevchenko National University, Ukraine
}

Paper received 03.04.18; Accepted for publication 07.04.18.

\begin{abstract}
https://doi.org/10.31174/SEND-Ph2018-161VI48-13
\end{abstract}
\begin{abstract}
Realia are mostly studied in terms of their functioning and reproduction in works of art. However, texts of literary study have not yet attracted sufficient attention from researchers. This article focuses on the phenomenology of Ukrainian-language realia in Taras Schewtschenko. Ein Ukrainisches Dichterleben - a biographical study written in German language by Alfred Jensen, the famous Swedish literary critic, and published in Vienna in 1916. A. Jensen was one of the first Western European researchers to have written a major research monograph about a Ukrainian author. Despite the fact that in this work there are many realia incomprehensible to the German-speaking reader, his merit is that apart from T. Shevchenko, he also disclosed a large stratum of Ukrainian culture to the European literary critical community. The purpose of the paper is to analyze the types and functions of Ukrainian-language realia as they appear in the given academic text, as well as to discuss approaches to adequate tactics of their rendition in German. The achievement of this goal involves solving the following tasks: to identify Ukrainian-language realia in A. Jensen's work; to classify them according to existing typologies; to characterize ways of their rendition in the German language; as well as to determine in which way the reproduction of realia influences representations of the general image of Ukraine and its culture in this German-language work. The specific nature of the studied material is that, while A. Jensen widely used Ukrainian realia in his original work, he was not a professional interpreter. Yet for the German reader the author materialises as a kind of a "translator" of the Ukrainian language, its national colouring, and the Ukrainian culture as a whole. Discrepancies in the linguistic-ethnic character between the native speakers and speakers of the language of translation have both a cultural and a historical basis. In addition, difficulties do not only lie in the language plane, but also in the plane of differences in cultures with their specific ideological, social and behavioural aspects. Therefore, when using realia in translation, it should be borne in mind that what is understandable to a native speaker of the language may cause misunderstanding with the recipient of the translated text due to the differences in worldview, initial knowledge, culture-specific metaphoricity and behavioural norms. In short, the perception of the same text by different audiences may not be the same.
\end{abstract}

Keywords: language realia, onyms, methods of translation, scientific style, semantic-thematic classification.

Introduction. Language realia as a representative of nonequivalent vocabulary are the object of numerous studies in the field of linguistics, cultural linguistics, translation studies etc. In most cases, realia are studied in terms of their functioning and reproduction in works of art; however, research texts have not yet attracted sufficient attention from researchers. This article focuses on the phenomenology of Ukrainian-language realia in Taras Schewtschenko. Ein Ukrainisches Dichterleben - a biographical study written in German language by Alfred Jensen, the famous Swedish literary critic, and published in Vienna in 1916. The purpose of the paper is to analyze the types and functions of Ukrainian-language realia as they appear in the given academic text, as well as to discuss approaches to adequate tactics of their rendition in German. The achievement of this goal involves solving the following tasks: to identify Ukrainian-language realia in A. Jensen's work; to classify them according to existing typologies; to characterize ways of their rendition in the German language; as well as to determine in which way the reproduction of realia influences representations of the general image of Ukraine and its culture in this Germanlanguage work.

The research on realia, as well as the peculiarities of their reproduction, found their description in works of numerous scholars, such as R. Zorivchak, V. Kopylov, N. Lyubchuk, A. Cherednichenko, S.Vlakhov, S. Florin, A. Suprun et al. However, their efforts present either a broad theoretical coverage of the problem, or their primary material is based exclusively on fiction.

It should be noted that frequent use of realia is a characteristic feature of research texts from various, but primarily, from humanitarian disciplines - history, ethnography, cultural studies, literary criticism, etc. This fact makes the issue of an adequate rendition of realia in academic literature an actual linguistic problem.

The specific nature of the studied material is that, while A. Jensen widely used Ukrainian realia in his original work, he was not a professional interpreter. Yet for the German reader the author materialises as a kind of a "translator" of the Ukrainian language, its national colouring, and the Ukrainian culture as a whole. This thought is also supported by I. Mindyuk - a translator of A. Jensen's work in Ukrainian, who quoted the words of the Slavic scholar Dr. V. Yagich: "The Swedish literary historian [...] Dr. Alfred Jensen who is amazingly familiar with many Slavic literatures." ..], promotes the Ukrainian poet Taras Shevchenko to full extent. He called his study "the poet's life", but it covers [...] not only the life of the poet, but also the historical presentation of the main subject of his poems - Ukraine and a comprehensive analysis of his poetic works. His unusually thrilling book is full of enthusiasm and surprise for the poet, whom the author as a connoisseur of literature not only locked in his heart, but also managed to make attractive to the reader of his study "[5].

Jensen was able to present the broad context of the Ukrainian historical and cultural life in T. Shevchenko's times not least due to the active use of realia in his biographical study: there are more than 400 units in the text. The prominence of realia plays the research text can be explained by the very definition of the functional style of scientific speech: its main function is cognitiveinformative, supplemented with the function of evidence. A work written in this style conveys a research finding, disclosing its truth, novelty and value. Various objects and 
phenomena of objective reality serve as the content of scientific texts that are studied and examined by scholars and specialists, and the results of research are described and interpreted in their papers. "The transfer of information received is inextricably linked with the installation of the speech quality that would allow an adequate transfer of information with the least obstacles, giving the recipient accurate objective information about the identified object and convince him of the correct interpretation" [author's translation 15, p. 42].

Realia as a carrier of specific information in a research text is an effective tool for realization of its main tasks - to inform, to prove and to convince. Whether authors succeed in reaching their goal - to communicate with the target audience - very much depends on the way they use this tool. When the authors attempt to address a foreign audience, they immediately face a complex and hard-tosolve problem. As Y.Retzker noted, when working with an academic text, an interpreter (and as mentioned above A. Jensen acted, in a sense, as an interpreter) must take into account the speech habits of the native speakers of the translated language without disrupting the natural perception of the document or text. Discrepancies of linguistic and ethnic character between the speakers of a foreign language and the language of translation can have both a cultural and historical basis and, moreover, pertain to current events [11]. In addition, difficulties do not only lie in the language plane, but also in the plane of differences in cultures with their specific ideological, social and behavioural aspects. Therefore, when using realia in translation, it should be borne in mind that what is understandable to a native speaker of the language may cause misunderstanding with the recipient of the translated text due to the differences in worldview, initial knowledge, culture-specific metaphoricity and behavioural norms. In short, the perception of the same text by different audiences may not be the same.

Material and Methods. The concept of realia is interpreted from different positions. V. Berkov, for example, uses the concept of "national and cultural realia, which represent non-equivalent vocabulary," namely the names of material culture items, historical facts, state institutions, names of national and folklore characters, mythological creatures that are unique to certain nations and peoples etc. [1, p. 134]. According to S. Ter-Minasova, national and cultural realia encompass vocabulary denoting objects and phenomena associated with the history, culture, economy and life of the country of another language, which differ completely or partially in their conceptual content from the mother tongue and, in turn, also conceptually and culturally pose difficulties for foreigners [12, p. 76].

Studying national and cultural realia, L. Nelyubin notes that these "conceptually equivalent words" in their form are no different from ordinary lexis. Whilst for a bilingual person, a bearer of two different languages in their specific cultures, they are understandable, a person speaking only one (native) language, is confronted with an unsolvable puzzle if there is no reference to special directories and dictionaries [8, p. 97]. Nelyubin includes the following four subcomponents in his definition of the realia concept: "1. Words and phrases denoting objects, concepts and situations absent in the practical experience of people who speak a different language; 2. Various factors studied by general linguistics and translation studies, such as the government structure of a particular country, the history and culture of a certain people, the language contacts of speakers of a particular language, etc., from the point of view of their reflection in a particular language; 3 . The objects of material culture are the basis of the nominative meaning of the word. 4. Words denoting national-specific features of life and living" [9, p. 178].

Researchers from different periods offered a large number of classifications of realia. For example, G. Tomakhin classifies realia according to the semantic feature in a group of denotative realia - lexical units, the semantic structure of which is completely filled with background lexical information, and suggests we should distiunguish the realia of daily life, speech etiquette and behavioural norms, geographical realia, socio-political realia, the realia of the education system, religion and culture [14]. Similarly, S. Proshina, proceeding from the semantic field of realia, distinguishes lexemes denoting social, military, educational phenomena; lexemes denoting traditions and customs; ergonyms and historical lexemes, everyday words, names of literary works and newspapers [10, p. 117-118].

A special question arises regarding inclusion or noninclusion of names in the notion of realia. The analysis of the source material proves the need to single out a separate class of onomastic realia, following some other scholars, who include names in the content of idioculturonomic vocabulary $[3,10]$. The class of onomastic linguistic and cultural realia includes anthroponyms, toponyms, names of literary characters, names of companies, museums, theatres, restaurants, shops, beaches, airports [3], zoonims [10], names of works of literature and art, historical facts and events in the life of the country, the names of state and public institutions [13].

Apart from the semantic-thematic classifications of realia, there is also a division according to the associative principle: realia form a class of associative [3, p. 37], or connotative realia [14]. According to G. Tomakhin's definition, connotative realia are lexical units which, while denoting simple concepts, at the same time express semantic and emotional shades [14, p. 41-42]. The class of associative/connotative realia includes lexical units denoting vegetative symbols, animalistic symbols, colour symbolics, folklore, historical and literary allusions, which are associated with the way of life, behaviour, traits, activities of historical, folklore and literary characters, historical events, myths, linguistic allusions, which usually imply a certain phraseological unit, a proverb, a saying, or a popular expression [3, p. 96-97]. S.Vlakhov and S. Florin point out that connotative words form a separate group and can include realia which to some extent are carriers of connotative meanings, since the content of the concept of "connotation" includes a certain colouring, which is the basic component of the content of any particular realia [4, p. 38]. The notion of colouring also means temporal colouring. As a linguistic phenomenon most closely associated with a particular culture, these lexical units respond quickly to all changes in the development of a society, among which one can always identify realianeologisms, historicisms and archaisms [7].

Summarizing the above definitions of realia, O. Biletska concludes that all language units of one language that 
denote its specific elements and have no equivalents in another language fall into the definition of realia [2]. For our purposes, it is advisable to combine the first and fourth meaning from L. Nelubin's definition and it is in this very sense that I will refer to realia in the following. When choosing appropriate ways to render realia either in the translation of a source text or in an academic study on another culture, one should proceed from the fact that realia belong to this or that class.

Results and Discussion.

Given the above classification of realia, I consider it advisable to classify the realia in A. Jensen's work according to semantic-thematic and denotative-connotative principles, while holding the opinion that it is the latter principle that allows us to determine the adequacy of the rendition of realia in a foreign text.

The most numerous groups of realia in Jensen's work are:

1) onomastic realia (60\% of all analyzed realia) including:

a) anthroponyms (for example, Skovoroda, Honta, Salisnjak, Hryhorij, Kateryna, Jakym Bojko, Jaroslawna)

b) toponyms (Kyryliwka, Moryntzi, Kopij, Buhorsky, SSubotiw, Chortytzja, Wolodymyr, Zhowti wody, Welykyj Luh)

c) hydronyms (Tschertomlyk, Dunaj, Dnipro, Borysthenes, Wolga)

d) biblionyms (the names of any written works - Taras Buljba, Gore ot uma, all names of poems by $\mathrm{T}$. Shevchenko, etc.);

e) ethnonyms, as well as exonyms and ethnophilisms (Ljachen, Saporoger, katzap, Chochly)

f) ergonyms, socionyms (Dekabristen, die St. Cyrill und Methodus Gesellschaft, Tschumaken, djak).

It should be noted that anthroponyms, toponyms and hydronyms are found both in the exposition of the biography of the poet, and in the analysis of his poetry. In the latter case, they are usually mentioned in connection with the original source - that is, the works of Shevchenko himself. All of these onyms, although belonging to different thematic classes, are undoubtedly connotative because in A.Jensen's work they already acquire the character of reminiscences and allusions to Shevchenko's works.

2) historical realia (Hetmanenland, Ruine, Ssitsch, Haydamakenzeit, Kolijiwschtschyna)

3) military and political realia (including titles and ranks - Ssotnyk, Osaul, isprawnik, Bojarin, Gossudar-Imperator, "die dritte Abteilung");

4) public realia (Prikas Malyja Rossii, Narodnoje Tschtjenije, pokrytka)

5) objects of culture and life (kytajka, Krippenspiel (wertep), bandura, kobsa, bajdaky). In this group, I also consider it appropriate to include measure and monetary units (Wersta, pjatak).

A. Jensen uses various methods to render realia. Onomastic realia are often transmitted by the method of transcription, and this corresponds to R. Zorivchak's opinion that "the only variety of realia that must be inevitably presented in the national similarity are anthroponyms and toponyms" [6, p. 98]. However, the author, realising that such a rendition would lead to excessive alienation of the text for a foreign reader, constantly combines transcription with other means. Thus, he gives an explanation of the names either in the text itself or in a footnote. For example: in the text there is an anthroponym Dolgorukij, and in the footnote - "Der Fürst Dimitrij D. Dolgorukij, Gendarmeriechef in Kiew zur selben Zeit"; "Pidkowa (Hufeisen, wegen seiner Stärke so benannt) war ein aus Moldau gebürtiger Kosak".

Here it is appropriate to recall the Vlahov's and Florin's arguments, who propose to approach the translation of onyms on the basis of semantics: "... the distribution of names should be conducted primarily along the line of their semantics. This allows us to consider 1) names-marks that do not have their own content, but merely name the object; 2) name-signs that have a certain semantic content; and 3) names which, depending on the context, change their relation to one of the first two groups" [4, p. 210]. If a proper name has a pronounced internal form, as in the second case ("Horseshoe"), then it is possible to apply methods other than transcription and transliteration. But since in an academic text the internal form of a name does not play a role as significant as in a literary one, the transliterated translation used by A. Jensen seems justified.

Also typical for A. Jensen is the combined renomination "Kosakenführer, wie Kosynskyj, Nalywajko ...", “der Philosoph und religiöse Dichter Skoworoda".

It is interesting to note that most of the transcribed onyms are given by A. Jensen according to the Ukrainian pronunciation, but there are also some in accordance with the Russian: "Zaporozskaja Starina", "Narodnoje Tschtjenije", "Walujew", "Turgenjeff". This seems justified if we conditionally divide all the realia of the text into endogenous and exogenous realia, that is, those that are endemic to the culture and epoch described, and those that are "alien" for them.

In the transfer of toponyms, A. Jensen, as a rule, approaches them as names-marks, giving the name in transcription, but in many cases considers it necessary to give its hypernymic along with its proper name. E.g.: "an den Flüssen Trubesch und Alta", "Uralfluss", "Festung Orsk", "In dem Dorfe Strjelna". Alternatively, the hyperonymic name is included in a more detailed explanation: "bei Trachtemyr, der ehemaligen Hauptstadt der Saporoger".

Analyzing the transfer of numerous biblionyms, which one can regularly come across in Jensen's literary study, the author adheres to two main tactics: 1. Names of Shevchenko's poems are transcribed, and the translation is given in parentheses. These transcribed tokens may not be realia in the narrow sense, but they denote common concepts. E.g.: "Dolja" (Lebensstern), "Trysna" (Gedächntnisfeier). Thus, the author elevates them into the rank of realia that play an important role for the presentation of Ukrainian culture or in Shevchenko's works. 2. There is also an inverse tactic - first a translation of the name, then a bracketed name for the transcription. E.g.: "Das aufgewühlte Grab" (Rosryta mohyla)", "Die Pest (Tschuma)". Several biblionyms exogenous to Ukrainian culture can be identified, which are presented in the German translation without the original name: "Die toten Seelen", "Abende auf dem Gutshofe nächst Dykanjka". This is probably due to the fact that by that time official German translations of the mentioned works by N. Gogol had already existed and they may have been well known in literary circles. 
Significant difficulties for the transfer, of course, are realia with a pronounced connotation, to which I attribute, first of all, ethnophilisms and social realia. Let us consider two examples. The first is the ethnophilism "Chochol". It occurs in a footnote which explains the derivative of the "Khokhol" (or "Chochol" in its German transliteration) dibasic composite "Chochlandija". The author presents it as follows: "Zopfland (Chochlandija)". In his explanation it says: "Die Russen geben dem Ukrainer den Spottnamen 'Chochol' wegen des Haarbüschels, das die saporogischen Kosaken trugen ..." A. Jensen abstained from a component semantic division of the word. The hypernym "Khokhol" is taken in the meaning of "long lock of hair" and is translated as "Zopf"; the second base of the composite token, borrowed from German, adjoins the first with the deletion of the Ukrainian morphological suffix, resulting in the formation of the composite "Zopfland". The downside of this rendition is the complete loss of the term's connotative value. For the German-speaking reader, the lexeme "Zopf" does not carry derogative connotations, which is why the onym can be perceived by the target audience as "The Country of Locks", that is, a country where people sported a popular haircut. In my opinion, it would be sufficient to give a transcription of realia with an explanation of its connotative meaning and the history of the origin of the ethnophilism "Khokhol". However, here, I assume, the author was guided by considerations on the similarity of the morpheme sounding "khokh" in the German "hoch", and consequently, tried to avoid the perception of the composite in the meaning of "highlands".

Another example is the lexeme "pokrytky". The content of this social realia is revealed by A. Jensen in a broader context. Having previously described T. Shevchenko's attitude to women, the author then introduces the realia of "pokrytka", giving a calibrated translation in brackets "Bedeckte" and further, in the text, explaines this phenomenon and the origin of the Ukrainian word. On the one hand, the author did his best to convey to the reader the significance of the social phenomenon expressed by this realia. On the other hand, however, A. Jensen's explanation seems too poeticized; one can not immediately understand that it is a woman who gave birth to an illegitimate child, and, consequently, all brutalities of reality - dishonesty, stigmatization on the part of society, public punishment - remain beyond attainment. This example confirms the validity of referring realia to non-equivalent vocabulary. Explanations, interpretations, and annotations in academic texts provide opportunities to explain to a reader the complexity of connotations that realia convey.

Conclusions. Thus, several conclusions can be drawn based from the above analysis: the decisive factor motivating the attribution of certain objects, events and phenomena to national cultural realia is, in most cases, their narrow national specific nature and colouring. In an academic text such language units require special attention, since they give it documentary accuracy and details. Given the genre specificity of the academic text, the most productive ways of conveying realia in another language are the use of explication or descriptive translation in various combinations with transcription, transliteration, loan translation and hypernymic renaming.

I believe that since this was one of the first Western European studies on Ukrainian culture, the author could have limited himself to some few transcriptions of realia since such a large amount considerably alienates the text for the reader and makes the whole piece incomprehensible. However, on the other hand, we should not forget that A. Jensen's work belongs to serious academic study, not to popular science, and, therefore, is designed for a very limited target audience - literary critics, historians, and culturologists. Accordingly, the study's main goal is to provide its readers with most accurate and complete information. To achieve this goal, in my opinion, it would have been appropriate to provide the material presented with a certain element of visualization. For example, toponymic realia would have been perceived much easier if maps of the territories where the described events took place had been provided, thus releasing the author from the pressure to give explanations of the geographical context.

A. Jensen was one of the first Western European authors to write a large academic study on a Ukrainian author. Whilst his work has many realia incomprehensible to the German-speaking reader, its merit lies in the fact that, apart from introducing the Ukrainian national poet $T$. Shevchenko, it has disclosed a large stratum of Ukrainian culture to the European literary critical community.

\section{REFERENCES}

1. Berkov, V. P. (2004) Dvuyazychnaya leksikografiya. Moskva: Astrel, 236.

2. Biletska, O. O. (2015) Movni realiyi yak verbalne vyrazhennya spetsifIchnykh rys natsionalnykh kultur. Kultura I mystetstvo $u$ suchasnomu sviti, 16, 6-13.

3. Vinogradov, V. S. (2001) Vvedenie v perevodovedenie (obschie i leksicheskie voprosy). Moskva: Izdatelstvo instituta obschego srednego obrazovaniya RAO, 224.

4. Vlahov, S., Florin, S. (1986) Neperevodimoe v perevode. Moskva: Mezhdunarodnye otnosheniya, 416.

5. Jensen, A. (1921) Taras Schewtschenko. Zhyttya ukrayinskogo poeta: lit. studiya. za dozvolom avt. z nim. per. Ivan Mandyuk. Peremyshl: Z drukarni Knollera I Syna, 106.

6. Zorivchak, R. P. (n.y.) Realiya i pereklad (na materiali anglomovnykh perekladiv ukrayinskoyi prozy), 216 .

7. Kabakchi, V. V. (2001) Praktika angloyazychnoy mezhkulturnoy kommunykatsyy. Sankt-Peterburg: Soyuz, 480.

8. Nelyubin, L. L. (2007) Lingvostilistika sovremennogo angliyskogo yazyka. Moskva: Flinta, Nauka, 254.

9. Nelyubin L.L. (2003) Tolkovyy perevodovedcheskiy slovar. Moskva: Flinta, Nauka, 320.

10. Proshina, Z. G. (2008) Teoriya perevoda. Vladivostok: Dalnevost. un-ta, 276.

11. Retsker, Ya. I. (2007) Teoriya perevoda i perevodcheskaya praktika. Ocherki lingvisticheskoy teorii perevoda. Moskva: R. Valent, 244.

12. Ter-Minasova, S. G. (2000) Yazyk i mezhkulturnaya kommunikatsyya Moskva: Slovo, 624

13. Tomahin, G. D. (1982) Amerika cherez amerikanizmy. Moskva: Vysshaya shkola, 256.

14. Tomahin, G. D. (1988) Realii-amerikanizmy. Moskva: Vysshaya shkola, 239.

15. Troyanskaya, E. S. (1976) K obshchey kontseptsyy ponimaniya funktsionalnyh stiley. Osobennosti stilya nauchnogo izlozheniya. Moskva: Nauka, 36-79.

16. Jensen, A. (1916) Taras Schewtschenko. Ein ukrainisches Dichterleben. Wien: Adolf Holzhausen, 182. 